\title{
Propagule Production by Phytophthora ramorum on Lilac (Syringa vulgaris) Leaf Tissue Left on the Surface of Potting Mix in Nursery Pots
}

\author{
Nina Shishkoff, Research Plant Pathologist, United States Department of Agriculture-Agricultural Research Ser- \\ vice, Foreign Disease/Weed Science Research Unit, Frederick, MD 21702
}

\begin{abstract}
Shishkoff, N. 2009. Propagule production by Phytophthora ramorum on lilac (Syringa vulgaris) leaf tissue left on the surface of potting mix in nursery pots. Plant Dis. 93:475-480.

Lilac leaf tissue infected with Phytophthora ramorum was placed on top of potting mix in pots and exposed to different watering regimes or different temperatures to determine if it could serve as a source of inoculum. If pieces of infected leaf were placed in pots containing healthy lilac plants kept under constantly moist conditions or under twice-a-day trickle irrigation for 1 month, inoculum production from infected tissue declined for the first 4 days but declined significantly less steeply under constantly moist conditions. At the end of the experiment, $28 \%$ of plants exposed to moist conditions developed root infections, whereas only $6 \%$ exposed to trickle irrigation did. If infected leaf pieces were placed on the surface of potting mix in pots containing lilacs and watered for $5 \mathrm{~min}$ one, two, or three times a day, inoculum production in the first 4 days declined but declined significantly more slowly in pots watered three times a day. If 0 to 16 leaf pieces were placed on the surface of potting mix in pots containing healthy lilacs under constantly moist conditions, leaf number significantly influenced the incidence of root infection. The effect of temperature was more difficult to quantify. At 10 or $15^{\circ} \mathrm{C}$, propagules included zoospores whereas, at 20 or $25^{\circ} \mathrm{C}$, they were predominantly sporangia. These results confirm the importance of detached leaves as inoculum producers under greenhouse conditions.
\end{abstract}

Phytophthora ramorum causes stem cankers on oak and foliar lesions and stem dieback on a number of plants $(3,26)$. Although the distribution of $P$. ramorum in U.S. forests is currently limited to parts of California and Oregon, there is potential for spread with the movement of water, soil, plants, and plant products. To avoid such spread, all stages of the life cycle of the organism need to be understood. $P$. ramorum shows adaptation to aboveground spread, most notably in its caducous sporangia, which can be spread by wind, rain, or stream water (4). However, the organism also has a soil phase, having been shown to survive in buried leaf tissue in forest soils for up to 24 weeks (5) and over a year under greenhouse conditions (20). Roots became infected under laboratory or greenhouse conditions (16,19-22) and under natural conditions (15). Fallen leaves may serve as a conduit by which inoculum might travel from aboveground parts to belowground parts or from belowground parts to aboveground parts.

Corresponding author: N. Shishkoff

E-mail: Nina.Shishkoff@ars.usda.gov

Accepted for publication 5 January 2009.

doi:10.1094/PDIS-93-5-0475

This article is in the public domain and not copyrightable. It may be freely reprinted with customary crediting of the source. The American Phytopathological Society, 2009.
Fallen plant material frequently has been mentioned as an inoculum sources for the aerial phase of Phytophthora diseases. In 1923, Petri reported on the ink disease of chestnuts in Italy, noting that the pathogen ( $P$. cambivora) sporulated in leaf mold and that such inoculum could be disseminated short distances during rainfall, and warned against mulching orchard trees with colonized leaf material (18). Newhook and Jackson (14), observing that fallen cocoa leaves could become infected with $P$. palmivora, felt that the presence of leaf litter on the ground in cocoa plantations would not protect pods from inoculum splashed up from soil but might serve as an alternative source of inoculum. In apple orchards affected by $P$. syringae, fallen leaves were heavily colonized and considered the principal means of inoculum accumulation in orchards and, therefore, along with soil, a source of inoculum infecting fruit on the tree by rain splash (8). In Florida, fallen fruit of citrus acted as a "trap" to move $P$. palmivora to the aerial phase from the soil phase (7). $P$. parasitica could survive at most 18 to 22 days in air-dried rhododendron tissue but, if such tissue was kept under moist conditions, sporangia were produced, particularly under flooded conditions after 24 to $48 \mathrm{~h}$ (10). Analysis of splash dispersal in a naturally infested nursery suggested that plants became infected from inoculum in or on the container base on which the pots were placed (10). P. parasitica in infected rhododendron leaf tissue overwintered in a
North Carolina nursery when buried $5 \mathrm{~cm}$ deep in a layer of pine bark used as a container base (11).

It is less common to see fallen plant material implicated as a vector for a pathogen to pass from the aerial phase to the soil phase. For example, if abscised leaves of Pieris japonica infected by Phytophthora citrophthora were left in pots, they caused crown rot and rot of feeder roots (6).

On some hosts, notably Camellia spp., $P$. ramorum causes severe defoliation of diseased leaves $(19,24)$. This article examines the behavior of $P$. ramorum on fallen leaves of lilac. Although $P$. ramoruminfected lilac plants do not defoliate as quickly as camellia, heavily diseased leaves will drop (21), and P. ramorum is known to sporulate heavily on infected lilac leaves (1), making it a good test subject. Although nursery conditions could not be replicated in a greenhouse containment facility, the effect of diseased leaves placed on the surface of potting mix in pots containing uninfected plants could be studied. Experiments examined the effect of different numbers of fallen, infected leaves, different types of irrigation, and different temperatures on sporulation of $P$. ramorum on infected lilac leaves.

\section{MATERIALS AND METHODS}

Isolate. The pathogen isolate (5-C) used in these experiments was recovered originally from Camellia sasanqua 'Bonanza' in California in 2003. It contained the same single nucleotide polymorphism profile as known isolates of U.S. clonal lineage NA1 typically found in California forests and nurseries (9). This isolate caused significant disease on a wide array of lilac cultivars (21). It was maintained in sterile water culture or on pimaricinampicillin-rifampicin-pentachloronitrobenzene agar selective medium $\mathrm{P}_{5} \mathrm{ARP}(12,23)$ and inoculated onto and reisolated from Rhododendron or Camellia spp. every 6 months to maintain pathogenicity. The culture is also maintained at $-80^{\circ} \mathrm{C}$ as part of the international collection of plant pathogens at the National Cancer Institute's Central Repository in Frederick, MD.

Production of infected leaf material. Lilacs (Syringa vulgaris) were inoculated with a sporangial suspension (approximately 2,000 sporangia/ml of water) and incubated in a dew chamber for 7 days at $20^{\circ} \mathrm{C}$. Very large black lesions were pres- 
ent on leaves after 7 days, frequently leading to leaf abscission. Such leaves were collected individually and the center of each large lesion was carefully removed as a $6.5-\mathrm{cm}^{2}$ leaf piece. The first measurement of inoculum production from such lesions was taken immediately after the tissue was cut from the lesion (see below).

Quantifying inoculum production from leaf lesions. In experiments described below, inoculum produced on leaf squares was collected by placing the leaf tissue in a 50-ml-capacity plastic vial along with $10 \mathrm{ml}$ of distilled water, capping the vial, and shaking it vigorously to dislodge sporangia. The contents of the vial were swirled, then examined under a dissecting microscope using dark-field illumination in order to see the density of suspended sporangia (the refractive sporangia were clearly visible, although zoospores were harder to see). If density was visibly high, sterile distilled water was added to vials until the concentration of sporangia was reduced to levels capable of being easily counted when aliquots were plated on selective media (below 300 $\mathrm{CFU} / \mathrm{ml}$ ). Aliquots were taken by withdrawing $2 \mathrm{ml}$ of inoculum suspension from the vial using a 3-ml-capacity disposable plastic syringe and adding $0.5 \mathrm{ml}$ to each of four plates of $\mathrm{P}_{5} \mathrm{ARP}$ selective media, the plates swirled to distribute the sporangial suspension over the entire surface. Plates were incubated at $20^{\circ} \mathrm{C}$ for 1 to 2 weeks and the number of colonies developing was then counted on each plate. At $20^{\circ} \mathrm{C}$, sporangia of $P$. ramorum germinate directly rather than form zoospores; therefore, it was assumed (and confirmed by direct observation in the following experiments) that whatever inoculum was present in the aliquot would remain in that form and germinate on agar. A colony count from selective media, therefore, would represent inoculum dislodged from the leaf piece. Colonies from $P$. ramorum grown on $\mathrm{P}_{5} \mathrm{ARP}$ and examined under dark-field illumination are unmistakable, with their highly refractive mycelium and large chlamydospores.

Constantly moist versus normal greenhouse conditions. Initially, it was unknown whether sporulation would occur on leaf tissue and, if it did, what variables would affect it. Therefore, one set of lilac plants was placed under normal greenhouse conditions at $25 \pm 3^{\circ} \mathrm{C}$ year-round with trickle irrigation twice a day for $2 \mathrm{~min}$ and another set placed under overhead misters controlled by an "electronic leaf mist controller" set to give constantly moist conditions. Lilac plants were planted in $10-\mathrm{cm}$-diameter plastic pots in potting mix (five parts of standard mix consisting of Promix BX, 30\%; leafgro, 30\%; coarse perlite, $16 \%$; coarse vermiculite, $8 \%$; peat moss, $8 \%$; sand, $8 \%$; plus $10-10-10$ fertilizer, 24 oz/yard ${ }^{3}$; lime, 18 oz/yard ${ }^{3}$; trace minerals, 12 oz/yard ${ }^{3}$; and wetting agent, 6 oz/yard ${ }^{3}$; this emended with three parts fine pine bark and two parts river sand; $\mathrm{pH}$ was 5.27 in $0.01 \mathrm{M} \mathrm{CaCl}_{2}$ ). Although both sets of plants received roughly the same amount of water each day (approximately $900 \mathrm{ml}$ ), the surface of soil in trickleirrigated plants dried out between waterings, whereas the soil surface for overhead-misted plants remained moist at all times. The sporulation on the pieces of infected lilac leaf was measured immediately (as soon as they had been cut from infected leaves); then, the leaf pieces were placed on the surface of potting mix in the pots containing healthy lilac plants. Leaf pieces were assayed at 1, 2, 3, 4, 7, 10, 14, 18 , and 22 days. At the end of the experiment, plants were examined for symptoms and four soil cores $(10 \mathrm{~mm}$ in diameter and $8 \mathrm{~cm}$ long) were taken from each pot. The cores were broken up in distilled water and root segments (generally $10 \mathrm{~mm}$ in length, branched or unbranched) were rinsed in distilled water to remove all soil particles and plated on $\mathrm{P}_{5} \mathrm{ARP}$ media (approximately 100 root segments per plant). There were six pots per treatment and the experiment was completed three times.

Overhead irrigation at one, two, or three times a day. Once it had been established that constant moisture was conducive to sporulation on leaf tissue sitting on the surface of potting mix, it was desirable to test plants under more typical greenhouse conditions. Infected leaf pieces were placed on the surface of potting mix in pots containing healthy lilac plants and watered using overhead irrigation for 5 min one, two, or three times a day. Leaf pieces were assayed at $0,1,2,3,4,5,7$, 10 , and 14 days. At the end of 30 days, root samples were taken (approximately 140 root segments per plant). There were five pots per treatment and the experiment was run four times.

Amount of infected fallen leaf tissue and root infection. To determine if root infection was influenced by the number of leaf pieces placed on the soil, $0,2,4,8$, or 16 leaf pieces were placed on the surface of pots containing well-established lilac plants (their root systems extended throughout the potting media). Soil was kept moist with overhead misting or watered using trickle irrigation twice a day; there were two pots per treatment and the experiment was run twice. Two additional experiments were run under moist conditions only. After a month, soil cores were taken from each pot and root segments (approximately 110 segments per plant) were plated on $\mathrm{P}_{5} \mathrm{ARP}$ media.

Propagules produced from infected leaf pieces on the surface of pots incubated at different temperatures. Infected leaf pieces were placed on the surface of potting mix in pots containing healthy plants kept in controlled-environment chambers set at $10,15,20$, and $25^{\circ} \mathrm{C}$ and watered for $2 \mathrm{~min}$ twice a day. The leaf pieces were assayed at $0,1,2,3$, and 4 days. There were four pots per treatment and the experiment was run three times.

Propagules produced from infected leaf pieces incubated in water at different temperatures. Because it was difficult to distinguish the effects of temperature from the effects of drying, infected leaf pieces were also placed in vials of sterile distilled water in controlled-environment chambers set at $10,15,20$, and $25^{\circ} \mathrm{C}$. The leaf pieces were assayed at $0,1,2,3$, and 4 days. There were three vials per treatment and the experiment was run three times.

Zoospore production at different temperatures. To try to distinguish between the effect of temperature on sporangial production on leaf pieces and on zoospore production from sporangia, known concentrations of sporangia in water were incubated at $10,15,20$, or $25^{\circ} \mathrm{C}$ for $2 \mathrm{~h}$ or overnight. Sporangia were produced from plugs of colonized V8 agar incubated for 2 days in $1 \%$ soil extract (25) and collected and diluted to approximately 500 sporangia/ml using a hemacytometer. This sporangial suspension was assayed by taking $2-\mathrm{ml}$ aliquots in duplicate. The $2 \mathrm{ml}$, collected by syringe, was delivered in $0.5-\mathrm{ml}$ volumes over four plates of $\mathrm{P}_{5} \mathrm{ARP}$ selective media as in previous experiments. The number of colonies counted from these plates served to determine the "time zero" concentration of $\mathrm{CFU}$ in the suspension. After the time zero assay, $10 \mathrm{ml}$ of the sporangial suspension were then placed in each of eight vials, and duplicate vials were placed in incubators set at 10, 15, 20, and $25^{\circ} \mathrm{C}$ for either 2 or $24 \mathrm{~h}$. At the end of the incubation period, suspensions were then examined under a dissecting scope and diluted with a known quantity of distilled water if necessary (i.e., if it looked as if there would be more than $300 \mathrm{CFU} / \mathrm{ml}$, making plates difficult to count) before being plated on $\mathrm{P}_{5} \mathrm{ARP}$. The number of colonies in the incubated samples was compared with the number of colonies in the original time zero sample in order to look for changes in inoculum concentration caused by zoospore release. These experiments were run five times at a $2-\mathrm{h}$ incubation period and five times at a $24-\mathrm{h}$ incubation period.

Statistical analysis. Regression analysis was done using the Proc Mixed feature in SAS (Statistical Analysis Software Institute [SAS], Cary, NC) to estimate slopes for regression lines and contrast the treatments. In the experiment to compare propagules production from infected leaf pieces on the surface of pots incubated at different temperatures, inoculum was only seen on day 1 ; therefore, instead of regression analysis over the first five time intervals, it was analyzed using General Linear Model (proc GLM; SAS) with a least squares means test to compare treatments at $P=0.05$. In experiments comparing propagule production from infected leaf 
pieces incubated in water at different temperatures and comparing zoospore production at different temperatures, propagule production did not lend itself to regression analysis, and treatments were analyzed at each time interval using GLM with least squares means to compare treatments at $P$ $=0.05$. Amount of root infection, measured as percent root colonization, did not yield normal data; therefore, $\chi^{2}$ analysis was used to look for differences in incidence among treatments.

\section{RESULTS}

Constantly moist versus normal greenhouse conditions. When infected leaf tissue was placed in pots under different moisture regimes (trickle irrigation twice a day or constantly moist conditions), a mixed model regression analysis run on the first five data points showed that propagule production declined over time for the first 4 days $(P=0.0001)$ but declined significantly more slowly under the constantly moist conditions $(P=0.0009)$ (Fig. 1c). After about the first 2 weeks, the leaves in the overhead misted treatment began to give off a new pulse of propagules; examination of plates showed that, whereas colonies arising on plates during the first 2 weeks predominantly arose from sporangia (Fig. 1a), as the leaf decayed, most colonies arose from chlamydospores (Fig. 1b). When the initially healthy lilac plants were examined at the end of a month, there was one infected attached leaf observed in the moist treatment in one replicate. Overall, $28 \%$ of the plants exposed under moist conditions developed root infections, whereas only $6 \%$ of the plants exposed to trickle irrigation did; a $\chi^{2}$ test comparing root infection by treatment showed this to be significant at $P=0.07$. However, these infections were slight: only 0.05 to $3.8 \%$ of root segments plated yielded colonies of $P$. ramorum.

Overhead irrigation at one, two, or three times a day. When sets of plants were watered one, two, or three times a day, a difference in the inoculum production of infected leaf tissue placed on potting mix was observed (Fig. 2). A mixed model regression analysis was run on the first five data points, showing that propagule production declined with time $(P<0.0001)$ but declined significantly more slowly in pots watered three times a day $(P<0.001)$. Infected roots were observed in all treatments $(5 \%$ of plants in pots watered once a day, $10 \%$ when watered twice a day, and $20 \%$ when watered three times a day). A $\chi^{2}$ test to see if watering frequency had an effect on the ability of infected leaf tissue to cause root infection was not significant. Again, the actual number of infected roots detected was low, from 0.6 to $1.8 \%$.

Amount of infected fallen leaf tissue and root infection. In experiments where
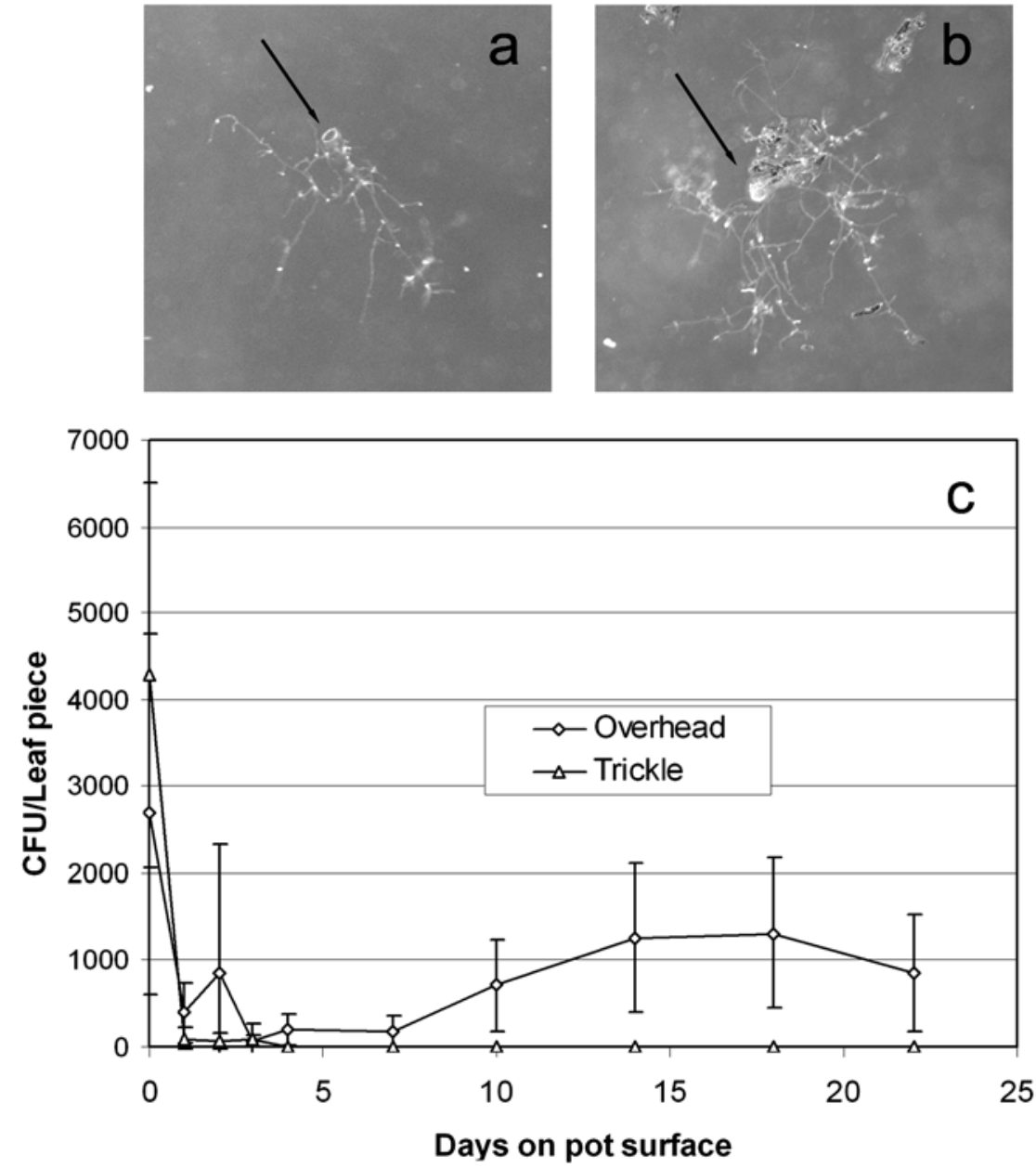

Fig. 1. a, Colony of Phytophthora ramorum growing on selective medium that has originated from a sporangium (arrow). b, Colony originating from a chlamydospore in a piece of decayed plant tissue (arrow). c, Effect of constant moisture (overhead misting) or watering twice a day (trickle irrigation) on propagule production from leaf pieces placed on the surface of potting mix for up to 22 days; the graph depicts the results of one of the three trials which clearly shows the decline in propagule production (CFU per $6.5-\mathrm{cm}^{2}$ leaf piece) in the first week (colonies visually identified as originating from sporangia) and then an increase in propagule production in the constant moisture treatment later on as the leaf decayed (colonies visually identified as originating from chlamydospores).

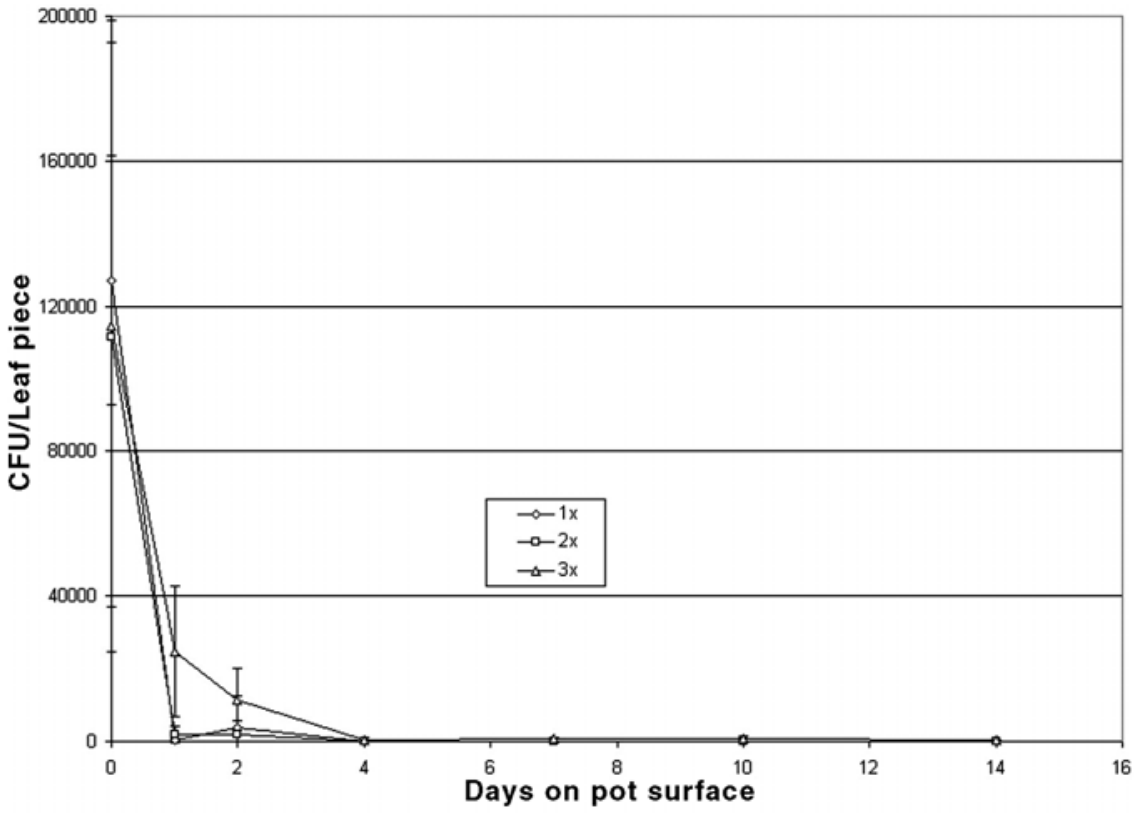

Fig. 2. Propagule production (CFU per $6.5-\mathrm{cm}^{2}$ leaf piece) of Phytophthora ramorum from leaf pieces placed on the surface of potting mix for 14 days and watered one, two, or three times a day for $5 \mathrm{~min}$. 
differing numbers of infected leaf pieces were placed on the surface of potting mix in pots containing healthy plants, no root infection was seen in pots with trickle

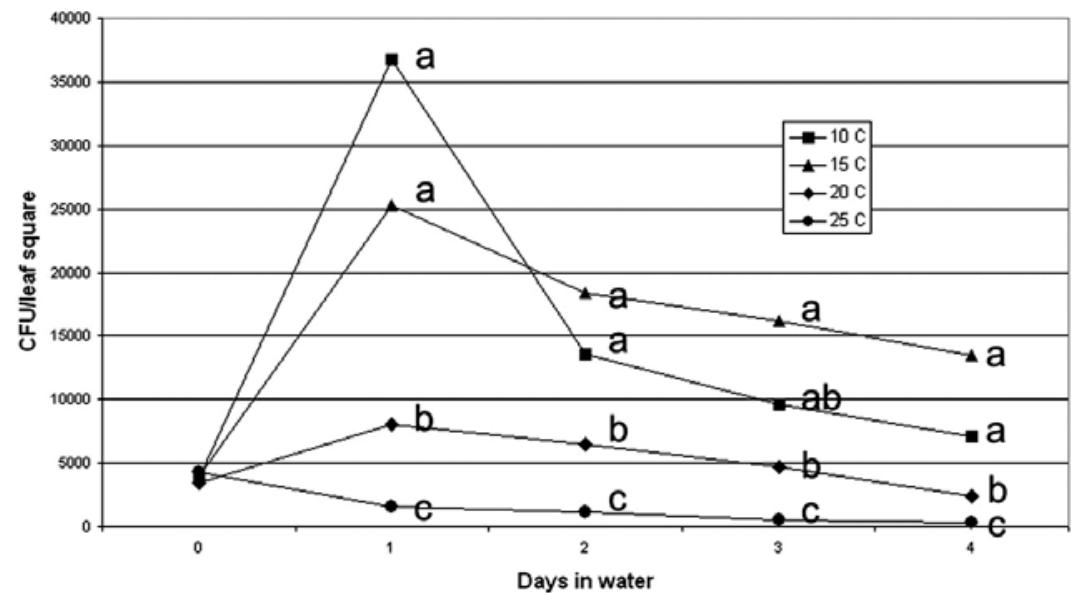

Fig. 3. Number of propagules of Phytophthora ramorum produced from $6.5-\mathrm{cm}^{2}$ leaf pieces incubated in $10 \mathrm{ml}$ of distilled water at $10,15,20$, or $25^{\circ} \mathrm{C}$. At days $1,2,3$, and 4 , a general linear model analysis was run to look for temperature effects on propagule production, and significant differences $(P \leq 0.05)$ are indicated by different letters.
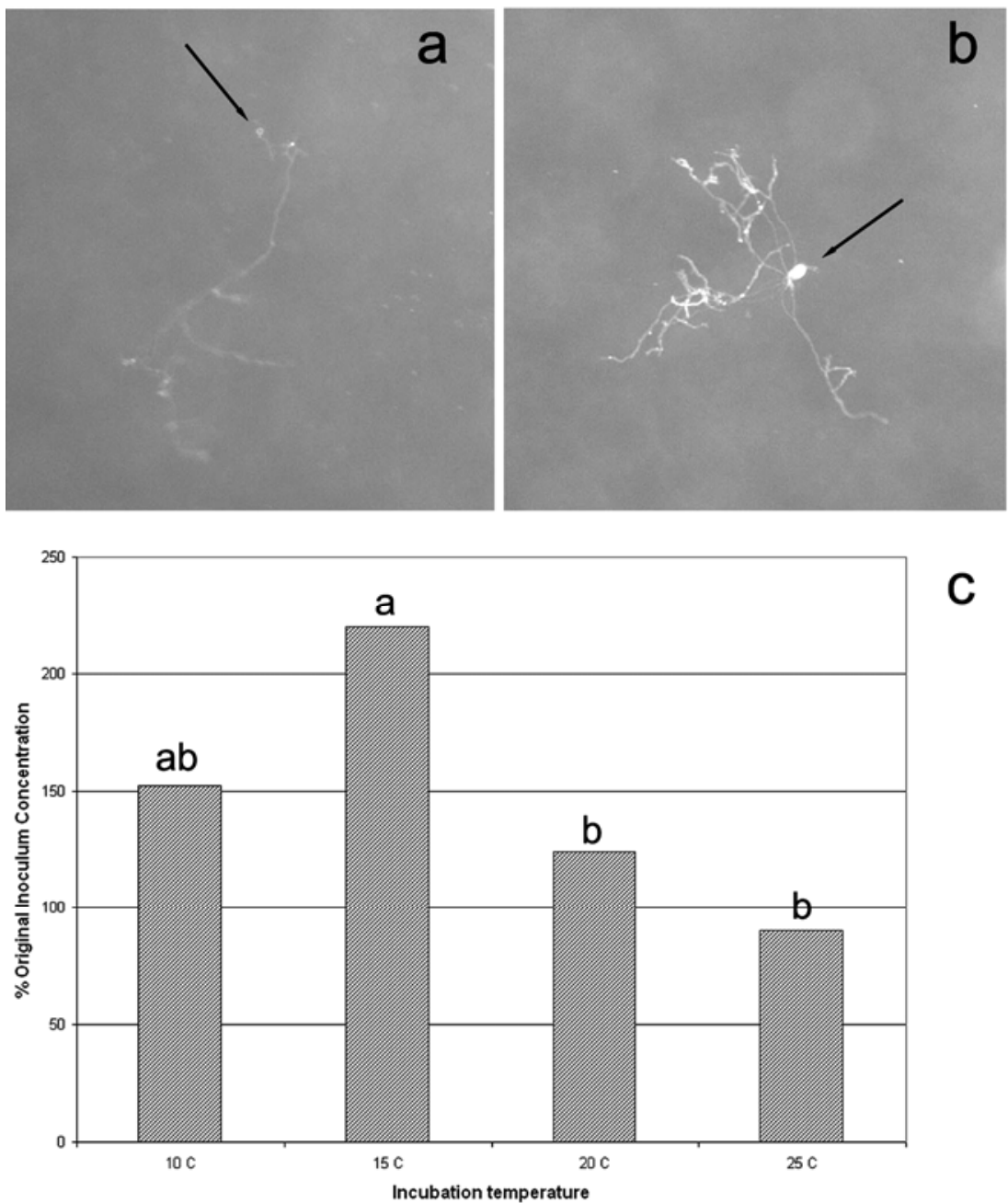

Fig. 4. a, Colony of Phytophthora ramorum growing on selective medium that has originated from a zoospore (arrow). b, Colony originating from a sporangium (arrow). c, Effect of temperature on propagule number (percent original inoculum concentration) when a known concentration of sporangia in suspension was incubated at $10,15,20$, or $25^{\circ} \mathrm{C}$. Bars labeled with different letters differed significantly $(P \leq 0.05)$ in a least squares means test. treatments receiving infected leaf pieces, from $38 \%$ of plants in pots with 2 to 4 leaf pieces, $62 \%$ of plants in pots with 8 leaf pieces, and $75 \%$ of plants in pots with 16 leaf pieces. A $\chi^{2}$ test to see if number of leaf pieces influenced frequency of root infection was significant at $P=0.02$. As with previous experiments, the actual percent root infection observed in these infected plants was 0.6 to $13.6 \%$.

Propagules produced from infected leaf pieces on the surface of pots incubated at different temperatures. Infected leaf pieces were placed on the surface of potting mix in pots containing healthy plants kept in controlledenvironment chambers set at 10, 15, 20, and $25^{\circ} \mathrm{C}$. Very few propagules were seen after day 1 . General linear models with a least squares test were run on data from day 1 , showing a significant effect of temperature on propagule number $(P=$ $0.0001)$. Significantly more propagules were produced from leaf pieces at $10^{\circ} \mathrm{C}$ than at 15,20 , or $25^{\circ} \mathrm{C}$, and significantly more propagules were produced at $15^{\circ} \mathrm{C}$ than at 20 or $25^{\circ} \mathrm{C}$.

Propagules produced from infected leaf pieces incubated in water at different temperatures. When leaf pieces were incubated at constant moisture (immersed in water) at different temperatures, comparisons done at days 1, 2, 3, and 4 showed that temperature had a significant effect on propagule number $(P=0.0001)$. In general, there were significantly greater numbers of propagules recovered from 10 and $15^{\circ} \mathrm{C}$ treatments than from 20 and $25^{\circ} \mathrm{C}$ treatments (Fig. 3). Visual examination of plates indicated that, at 10 or $15^{\circ} \mathrm{C}$, many colonies arose from zoospores whereas, at 20 or $25^{\circ} \mathrm{C}$, most arose from sporangia. It was impossible, therefore, from these data, to separate an effect of temperature on sporangial production from one on zoospore production.

Zoospore production at different temperatures. After sporangial suspensions were incubated for $2 \mathrm{~h}$ at 10, 15, 20, or $25^{\circ} \mathrm{C}$, no significant difference in propagule number among treatments was observed $(P=0.31)$. After $24 \mathrm{~h}$, significantly more colonies $(P=0.05)$ were recovered from suspensions incubated at $15^{\circ} \mathrm{C}$ than at 20 or $25^{\circ} \mathrm{C}$, with colony number at $10^{\circ} \mathrm{C}$ intermediate (Fig. $4 \mathrm{c}$ ). Visual observation of agar plates showed more colonies arising from zoospores (Fig. 4a) at 10 and $15^{\circ} \mathrm{C}$ than at 20 or $25^{\circ} \mathrm{C}$, where colonies arising from sporangia predominated (Fig. 4b).

\section{DISCUSSION}

These results confirmed the importance of infected leaves on the pot surface as inoculum producers under greenhouse conditions and also confirmed that cool, moist conditions are more conducive to inoculum production that warm, dry conditions. 
Inoculum could be produced in significant amounts on infected lilac leaves on the surface of potting mix, although wide variation was observed from leaf to leaf. Inoculum from infected leaves on the surface of pots kept in continuously moist conditions continued to be produced for up to 22 days. Moisture was clearly an important factor, with significantly more inoculum being produced on leaves in pots watered three times a day than in pots watered once or twice a day. Moisture may have been more significant a factor for lilac leaves, with their thin texture, than it would be for camellia or other thicktextured leaves. It was more difficult to gauge the importance of temperature because, in experiments where containerized plants were incubated at different temperatures, the possible effect of temperature on inoculum production was confused by the likely interaction with desiccation of leaf pieces on the surface of potting mix at the higher temperatures. In experiments done on leaf pieces submerged in water, more propagules were recovered from vials incubated at 10 or $15^{\circ} \mathrm{C}$; however, it was clear that zoospore production occurred at the lower temperatures. Zoospore production was difficult to quantify even when aliquots of a known concentration of sporangia in aqueous solution were incubated at different temperatures. Results were variable and the number of colonies recovered per vial after $24 \mathrm{~h}$ of incubation was often less than the time zero concentration, suggesting that mortality was also occurring.

More infected leaf tissue placed on the surface of pots led to a greater incidence of root infection. However, the amount of root infection in lilac plants exposed to infected leaves, if measured as percent root infection of segments plated on selective media, was quite low (at most 13.6\%) after 1 month under our greenhouse conditions. In previous work to determine the infection potential of lilac roots under optimum conditions for infection (21), when $25 \mathrm{~S}$. vulgaris were drenched with $15 \mathrm{ml}$ of a sporangial solution of approximately 3,000 sporangia/ml, $64 \%$ of the plants were infected after 1 month, at an average of $11.8 \%$ (washed roots) or $6.6 \%$ (roots surface sterilized in $10 \%$ bleach for $10 \mathrm{~min}$ before being plated). Under the same conditions, $60 \%$ of the positive controls (Viburnum tinus) became infected at $18.0 \%$ (washed) or $3.5 \%$ (surface sterilized). Root infections have been shown to spread in the vascular system to aboveground plant parts in Rhododendron spp. (16); therefore, even a small amount of infection might be significant in the disease cycle in some hosts. Even if systemic spread did not occur, if the root infections persisted over time, they might serve as a reservoir of disease, possibly splashing inoculum onto healthy fallen leaves or healthy leaves still attached to the plant.
Under field conditions in Europe, Neubauer et al. (13) suggested that $P$. ramorum did not spread well from plant to plant. Investigations of leaf litter and the pattern of spread indicated that, in their study, $P$. ramorum had colonized the ground and that inoculum on the ground has been transmitted to aerial plant parts via rain splash.

If abscised leaves were allowed to remain in proximity to containerized plants, the inoculum produced might also be spread in irrigation runoff. Sporangia, zoospores, and chlamydospores could also infest soil under pots in nurseries. It is not clear how long this inoculum would persist and whether such infested soil could lead to the infection of plants placed on top of it. Healthy container plants in pots placed on contaminated surfaces in container areas became infected with Phytophthora spp. (17). There have been "recurrent" infections of plants in nurseries where diseased plants were detected and removed. In 2005, the California Department of Food and Agriculture identified $53 P$. ramorum-positive California nurseries, 8 of which had recurrent infections (2), and it is not clear if the recurrence was due to a new introduction of diseased stock or infection of healthy plants from some source of inoculum persisting in the nursery.

This work agrees with that of Tjosvold et al. (24), where plants were inoculated under natural conditions in a simulated nursery and leaf disks taken from lesions were placed in water. Flooded camellia leaf disks were capable of producing chlamydospores and sporangia 8 to 12 weeks after initial inoculation, with the fall and winter more conducive to the production of these propagules than the other seasons. Flooded rhododendron leaf disks produced sporangia for 12 to 20 weeks after inoculation and chlamydospores 4 to 20 weeks after inoculation, with the fall and winter generally more conducive to the production of these propagules.

Best management practices for containerized plant nurseries should continue to include enjoinders to remove and destroy plant litter and also to water sparingly and in the early part of the day to reduce the threat of ramorum blight in a nursery setting.

\section{LITERATURE CITED}

1. Beales, P. A., Schlenzig, A., and Inman, A. J. 2004. First report of ramorum bud and leaf blight (Phytophthora ramorum) on Syringa vulgaris in the UK. Online. New Disease Reports Volume 9, http://www.bspp.org.uk/ndr/

2. California Oak Mortality Task Force. 2007. Nursery Chronology. Online. Retrieved December 2007 from http://nature.berkeley.edu/ comtf $/ \mathrm{html} /$ chronology.htm

3. Davidson, J. M., Werres, S., Garbelotto, M., Hansen, E. M., and Rizzo, D. M. 2003. Sudden oak death and associated diseases caused by Phytophthora ramorum. Online. Plant Health Progress doi:10.1094/PHP-2003-0707-01-DG

4. Davidson, J. M., Wickland, A. C., Patterson, H. A., Falk, K. R., and Rizzo, D. M. 2005.
Transmission of Phytophthora ramorum in mixed-evergreen forest in California. Phytopathology 5:587-596.

5. Fichtner, E. J., Lynch, S. C., and Rizzo, D. M. 2005. Seasonal survival of Phytophthora ramorum in soils. (Abstr.) Phytopathology 95:S29.

6. Gerlach, W. W. P., Hoitink, H. A. J., and Schmitthenner, A. F. 1976. Phytophthora citrophthora on Pieris japonica: infection, sporulation, and dissemination. Phytopathology 66:302-308.

7. Graham, J. H, Timmer, L. W., Drouillard, D. L., and Peever, T. L. 1998. Characterization of Phytophthora spp. causing outbreaks of citrus brown rot in Florida. Phytopathology 88:724729.

8. Harris, D. C. 1979. The occurrence of Phytophthora syringae in fallen apple leaves. Ann Appl. Biol. 91:309-312.

9. Kroon, L. P. N. M., Verstappen, E. C. P., Kox, L. F. F., Flier, W. G., and Bonants, P. J. M 2004. A rapid diagnostic test to distinguish between American and European Populations of Phytophthora ramorum. Phytopathology 94: 613-620.

10. Kuske, C. R., and Benson, D. M. 1983. Overwintering and survival of Phytophthora parasitica causing dieback of Rhododendron. Phytopathology 73:1192-1196.

11. Kuske, C. R., and Benson, D. M. 1983. Survival and splash dispersal of Phytophthora parasitica causing dieback of Rhododendron. Phytopathology 73:1188-1191.

12. Mitchell, D. J., Kannwischer-Mitchell, M. E., and Zentmyer, G. A. 1986. Isolating, identifying, and producing inoculum of Phytophthora spp. Pages 63-66 in: Methods for Evaluating Pesticides for Control of Plant Pathogens. K. D. Hickey, ed. American Phytopathological Society, St. Paul, MN.

13. Neubauer, C., Gliessmann, J., and Beltz, H. 2006. $\mathrm{Zu}$ den Ausbreitungswegen von Phytophthora ramorum an Rhododendron und Viburnum auf Container-Stellflächen. Gesunde Pflanz. 58:185-191.

14. Newhook, F. J, and Jackson, G. V. H. 1977 Phytophthora palmivora in cocoa plantation soils in the Solomon Islands. Trans. Br. Mycol. Soc. 69:31-38.

15. Parke, J. L., Bienapfl, E. Oh., Rizzo, D., Hansen, E., Buckles, G., Lee, C., and Valachovic, Y. 2006. Natural infection of tanoak seedling roots by Phytophthora ramorum. (Abstr.) Phytopathology $96: \mathrm{S} 90$.

16. Parke, J. L., Grunwald, N., Lewis. C., and Fieland, V. 2008. A systems approach for managing Phytophthora diseases in production nurseries. (Abstr.) Phytopathology 98:S121.

17. Parke, J. L. C., and Lewis, C. 2007. Root and stem infection of rhododendron from potting medium infested with Phytophthora ramorum. Plant Dis. 91:1265-1270.

18. Petri, L. 1923. Sul mododi diffondersi del mal dell' inchiostro del Castagno e sul merzi pui efficacy per combatterio. Nuovi Ann. Min. Agric. 3:3-19.

19. Shishkoff, N. 2006. Susceptibility of camellia to Phytophthora ramorum, the "sudden oak death' organism. Online. Plant Health Progress. doi:10.1094/PHP-2006-03S-01-RS

20. Shishkoff, N. 2007. Persistence of Phytophthora ramorum in soil mix and roots of nursery ornamentals. Plant Dis. 91:12451249.

21. Shishkoff, N. 2007. Susceptibility of some lilac cultivars and other members of the Oleaceae to Phytophthora ramorum. Online. Plant Health Progress doi:10.1094/PHP-20071101-02-RS

22. Shishkoff, N., and Senesac, A. 2005. Susceptibility to Phytophthora ramorum of roots and shoots of common container weeds. (Abstr.) Phytopathology 95:S96. 
23. Timmer, L. W., Sandler, H. A., Graham, J. H., and Zitko, S. E. 1988. Sampling citrus orchards in Florida to estimate populations of Phytophthora parasitica. Phytopathology 78: 940-944.

24. Tjosvold, S. A., Chambers, D. L., and Blomquist, C. L. 2007. Seasonal symptom expression, laboratory detection success, and sporula- tion potential of Phytophthora ramorum on rhododendron and camellia. In: Sudden Oak Death Sci. Symp. III. Santa Rosa, CA. Online. http://nature.berkeley.edu/comtf/sodsymposium/ PDF/Abstracts/Seasonal\%20Symptom\%20Exp ression-Tjosvold.pdf

25. Tooley, P. W., Kyde, K. L. and Englander, L. 2004. Susceptibility of selected ericaceous or- namental host species to Phytophthora ramorum. Plant Dis. 88:993-999.

26. Werres, S., Marwitz, R., Man In't Veld, W., De Cock, A. W. A. M., Bonants, P. J. M., De Weerdt, M., Themann, K., Ilieva, E., and Baayen, R. P. 2001. Phytophthora ramorum sp. nov., a new pathogen on Rhododendron and Viburnum. Mycol. Res. 105:1155-1165. 